\title{
The most appropriate mentoring practice by a cooperating teacher during practical teaching internship
}

\author{
Melki H. ${ }^{\mathrm{ABCD}}$, Bouzid M.S. ${ }^{\mathrm{BC}}$, Fathloun M. ${ }^{\mathrm{AD}}$ \\ Higher Institute of Sport and Physical Education, ISSEP Ksar Saï, Tunisia
}

Authors' Contribution: A - Study design; B - Data collection; C - Statistical analysis; D - Manuscript Preparation; E - Funds Collection.

\begin{abstract}
Purpose: $\quad$ The aim of this research is to examine the degree to which the quality and frequency of mentoring by cooperating teachers during practical teaching internship influence the professional competence of future teachers.

Material: $\quad$ To verify our proposed object, we conducted a research using a questionnaire distributed, during 2016-2017 school year, The analyses are based on a sample of more than 164 Tunisian physical education trainees and 96 cooperating teachers who participated in a pre-test and post-test study.

Results: $\quad$ The results indicate that the quality and frequency of mentoring explain the success of starting a professional life. In terms of learning, mentoring that follows helpful rather than transmissive principles stimulates the performance, motivation and job satisfaction of future teachers and reduces emotional fatigue.

Conclusions: Cooperating teachers training should include supervision practice themes to provide their trainees with real practice opportunities and to support them as needed.

Keywords: professional development, transmission, mentoring, cooperating teacher, trainees.
\end{abstract}

\section{Introduction}

The research results of Hoyle et al [1] indicated that much of the current teaching research agenda encompasses practical knowledge, personal practical knowledge, and knowledge about educational content. In this sense, Eraut [2] confirmed that all these types of cognitions refer to the teachers' knowledge expressed in practice. However, there is still very little information on the processes of interpretation and personalization of theory and its integration into the conceptual contexts that guide their actions in practice [3]. According to Fantilli and McDougall [4] the practical teaching internship is often described as a stressful period in the life of future teachers. Haser and Star [5] research on the process of supervising students in initial education states that supervision is one of the key factors that determine the success of novice teachers in the early stages of their teaching experience. In Kram's [6] definition, mentoring is usually considered a form of developmental assistance offered to a novice by an older person with experience in his field. Mentoring is also considered as a developing practice [7], a contemporary concept, in which values, rules, expertise are transferred from one person to another. In the education and training context, training mentoring represent as an integral part of all teacher education programs in the field [8]; [9]. Melki et al [10], indicates that initial training in physical education in Tunisia is identified by a double characteristic: a set of theoretical courses given by a university professor and practical field experience led by a cooperating teacher. As many authors consider traineeship to be the most important element of their training. The cooperating teacher depends on the success of the traineeship [11] and their participation is particularly important [12]. Cooperating teachers are those who spend the most time with future teachers [13] (C) Melki H., Bouzid M.S., Fathloun M., 2018 doi:10.15561/20755279.2018.0607 and who have an impact on the identity formation of preservice trainees [14], According to Beck and Kosnik [15] cooperating teacher is a key element, acting as a support and guide to the teaching-learning process, and as an important source of emotional support. In Ingersoll and Strong [16] research, the role of cooperating teachers and their effects in the process of integration into professional life has received much attention. In the context of the physical education training of teachers [17] demonstrated that cooperating teachers perceive their role in the training of future teachers as the most important part of learning to teach. With the same idea, Smith [18] argued that cooperating teachers have the most significant influence on the quality of trainees' training experience. Graham [19] points out that there are two essential elements to the success of the traineeship: first, the cooperating teacher and the traineeship site. The cooperating teacher role is crucial for the growth and development of future teachers. It has consistently emerged from the literature that future teachers perceive their cooperating teachers as one of their most important sources of significant support during the practical internship [20]. Lindgren [21] indicated that cooperating teachers provide crucial practical advice on teaching and reflect on working methods, they also look at the positive and negative aspects of lessons.

Some of the research on trainee mentoring has shown that the support of a cooperating teacher is positively associated with teacher efficacy [22], educational engagement [23] and best pedagogical practice [24]. There is consistent evidence that trainees perceive their cooperating teachers as one of the main sources of support during pre-service education training [20]. Cooperating teachers provide essential practical advice on teaching and the role of teachers [25]. In addition, in the presence of a cooperating teacher, future teachers discuss the positive and negative aspects of the lessons. Studies on teacher 
mentoring have shown that the support of a cooperating teacher is positively correlated with teacher effectiveness, educational engagement [23], and improved teaching practices [26].

Brooks and Sikes [27] studied the mentoring psychology process and stated that the psychological support of the cooperating teacher includes the development of self-confidence, the promotion of selfesteem, as well as the ability to listen and the desire to become more autonomous [28]. This assistance is particularly useful in the first year of teaching since future teachers must adapt to their new work environment. Rhodes [29] believes that psychological support reduces stress and improves job satisfaction. Olds et al [30] research results presented that mentoring affects future teachers through two closely related models: First, a model proposes the transmission of knowledge. A second model introduces the concept of educational mentoring. According to Sfard [31] mentors perceive their role as expert teachers and pass on their knowledge in a structured relationship of hierarchy. They add that in educational mentoring, cooperating teachers act with their novices in reflecting that helps them to learn in their practice. In summary, Wang and Odell [32] concluded that the two models presented show resemblances with two paradigms of learning theory, a knowledge transmission model based on behaviorist learning theories, in which trainees are becoming passive to information. This mentoring model aligns with mentoring reflections focused on the transmission of learning [33]. In fact, for Kessels et al [34] these two models; knowledge transformation and educational mentoring reflect a theory of professional development. According to which future teachers develop their own knowledge by linking new information to their previous knowledge. This research suggests that mentoring can have a positive influence on the teacher's transition to the teaching profession. However, there is very little research on the effects of mentoring on the development of the professional skills of future teachers. Few studies examine differences in the quality of mentoring offered [23, 35]. Consequently, there is limited knowledge about the mentoring practices that best support teacher development during practice internship.

This study intended to determine the extent to which the quality and frequency of mentoring predict the development of the professional competence of future teachers during the practical teaching internship. In particular, we study the effects of mentoring on teacher effectiveness, teacher motivation, perceptions of learning, emotional fatigue, and job satisfaction.

\section{Material and methods}

\section{Participants}

The sample was recruited from various randomly selected schools in four governorates in Greater Tunis (Manouba, Tunis, Ben Arous, and Ariana). All future teachers in the sample will teach physical education in college. The first group of trainees included an average of 98 persons aged 22.4 years $(\mathrm{SD}=2.0$ years) and predominantly male $(65.4 \%)$. The second group consisted of 66 persons with an average age of 23.3 years $(\mathrm{SD}=3.1$ years) and $63.3 \%$ female. A total, 162 future teachers from both groups participated in the first level of measurement and $103(74.2 \%)$ continued in the second level of measurement. Participants in the longitudinal sample were, on average 22.8 years old ( $\mathrm{SD}=2.6$ years) at the start of the study and the majority were male $(73.9 \%)$. Participation in the study was voluntary.

\section{Research design}

The first physical education teacher training in Tunisia took place over a period of three years and is entitled to a bachelor's degree. Indeed, in the third year of training, a single preparatory training for professional life took place for a period of one continuous school year. According to Schwarzer et al [36] all future teachers are assigned to cooperating teachers who provide supervision, feedback and advice during the internship period.

This study used a pre-test and post-test protocol with two groups and two measurement levels. The future teachers of the first group were evaluated at the end of the first semester of the school year (from the beginning of the internship to the end of the first semester). Their second group partners are evaluated at the start and end of the second semester of the practical training year, so both groups were skilled at the same time interval. This conception allows us to explore the evolution of the characteristics of future teachers and the relevance of mentoring for cooperating teachers in this integration period.

\section{Procedures}

Firstly, as part of a mentoring assessment focusing on professional development and transmission mentoring, we asked future teachers to assess their level of satisfaction with their cooperating teachers. This does not include the content of their interactions. Three items measured professional development mentoring (Table 1); two items measured mentoring focused on transmission. The assessment model was a 6-point scale from (1) strongly disagree to (6) strongly agree.

Secondly, we evaluated the quantity of mentoring based on the frequency of interactions between the cooperating teacher and the trainee. The frequency is assessed by a single question: "On average, how often did you talk to your cooperating teacher during your practical training? Responses are made on a 6-point scale ranging from (1) less than once a month to (6) all sessions. Responses that indicated trainee-cooperative teacher interactions "several times a week" or "every day" were recorded as ' 1 ' and all other responses that indicated less frequent interactions were recorded as ' 0 '.

Thirdly, to support research, we used a scale to measure the cooperating teacher's efficacy [36] and to determine the professional abilities that exist among mentors. It focused on two main areas: (a) professional development, (b) knowledge transfer. For each of these two topics, cooperating teachers may have specific efficacy needs. It seems that these important items are fundamental to successful mentoring. Each item is developed following 
Bandura's social cognitive theory $[37,38]$. We note that future teachers are asked to assess their agreement with 10 statements on a 4-point Likert scale ranging from (1) strongly disagree to (4) strongly agrees.

Statistical Analysis

Analyses were performed using statistical software SPSS 16 (Statistical Package for social science) program. The following variables were calculated using descriptive statistic: frequencies, percentages, and Cronbach alpha index. Assessment of statistical significance between male and female student teachers was performed using a Chi-square. Correlation between CT behavior on health and attractiveness of PE-ST was applied. Value less than
0.05 was considered statistically significant.

\section{Results}

The comparison between the participating revealed no significant differences in gender, but the participants in either evaluation were about two years younger. Furthermore, we found no statistically significant differences between the two groups in the effectiveness of outcome variables, teacher motivation, transmissive and professional development perceptions, and fatigue emotional.

The development mentoring scale demonstrated an internal consistency of $\alpha=0.84$. ; Transmission mentoring,

Table 1. Factor saturation for exploratory and confirmatory scaling analysis

\begin{tabular}{|c|c|c|c|c|c|}
\hline \multirow[t]{2}{*}{ Factors } & \multirow{2}{*}{$\begin{array}{l}\text { Items } \\
\text { My cooperating teacher: }\end{array}$} & \multicolumn{2}{|l|}{$\begin{array}{l}\text { Results } \\
\text { of ESA }\end{array}$} & \multicolumn{2}{|c|}{$\begin{array}{l}\text { Results } \\
\text { of the CSA }\end{array}$} \\
\hline & & Factor 1 & Factor 2 & Factor 1 & Factor 2 \\
\hline \multirow{3}{*}{$\begin{array}{l}\text { Mentoring } \\
\text { centered on } \\
\text { Transmission }\end{array}$} & $\begin{array}{l}\text { Says what I should } \\
\text { do to get better. }\end{array}$ & $0.14 *(.05)$ & $0.82 *(.04)$ & - & $0.79 *(.03)$ \\
\hline & $\begin{array}{l}\text { Had some suggestions as to how I } \\
\text { should teach the theme of the course. }\end{array}$ & $0.10(.05)$ & $0.70 *(.03)$ & - & $0.68 *(.03)$ \\
\hline & $\begin{array}{l}\text { Telling me what I'm supposed to do in } \\
\text { another way in lessons. }\end{array}$ & $0.00(<.01)$ & $0.76 *(.03)$ & - & $0.71 *(.03)$ \\
\hline \multirow{4}{*}{$\begin{array}{l}\text { Mentoring } \\
\text { centered on } \\
\text { professional } \\
\text { development }\end{array}$} & $\begin{array}{l}\text { Allows me to make progress more on } \\
\text { my own. }\end{array}$ & $0.82 *(.04)$ & $0.02(.01)$ & $\begin{array}{l}0.86 * \\
(.04)\end{array}$ & - \\
\hline & $\begin{array}{l}\text { Allows me to familiarize myself with } \\
\text { various teaching approaches. }\end{array}$ & $0.80 *(.04)$ & $0.08(.04)$ & $\begin{array}{l}0.73^{*} \\
(.04)\end{array}$ & - \\
\hline & $\begin{array}{l}\text { Allows me to formulate my personal } \\
\text { statements. }\end{array}$ & $0.62 *(.03)$ & $0.29 *(.04)$ & $\begin{array}{l}0.78^{*} \\
(.04)\end{array}$ & - \\
\hline & $\begin{array}{l}\text { Is a source of reflection that invites } \\
\text { self-examination. }\end{array}$ & $0.67 *(.03)$ & $0.03(.04)$ & $\begin{array}{l}0.69 * \\
(.03)\end{array}$ & - \\
\hline
\end{tabular}

Note: $\mathrm{CSA}=$ Confirmatory Scaling Analysis; $\mathrm{ESA}=$ Exploraty Scaling Analysis. ${ }^{*} \mathrm{p}<0.05$.

Table 2. Descriptive statistics of mentoring practices.

\begin{tabular}{|c|c|c|c|c|c|c|c|c|}
\hline \multirow{2}{*}{ Result } & \multirow{2}{*}{ Groups } & \multirow{2}{*}{$\mathbf{N}$} & \multicolumn{2}{|c|}{ period 1} & \multicolumn{2}{|c|}{ period 2} & \multirow{2}{*}{$\mathbf{t}$} & \multirow{2}{*}{$\mathbf{p}$} \\
\hline & & & M1 & SD1 & M2 & SD2 & & \\
\hline \multirow{2}{*}{ Mentoring Frequency } & 1 & 98 & $*$ & $*$ & 0.56 & 0.50 & $*$ & $*$ \\
\hline & 2 & 66 & $*$ & $*$ & 0.72 & 0.47 & $*$ & $*$ \\
\hline \multirow{2}{*}{$\begin{array}{l}\text { Mentoring centered on the } \\
\text { development }\end{array}$} & 1 & 98 & $*$ & $*$ & 4.53 & 1.18 & $*$ & $*$ \\
\hline & 2 & 66 & $*$ & $*$ & 4.75 & 1.20 & $*$ & $*$ \\
\hline \multirow{2}{*}{$\begin{array}{l}\text { Mentoring centered on } \\
\text { Transmission }\end{array}$} & 1 & 98 & $*$ & $*$ & 3.33 & 1.44 & $*$ & $*$ \\
\hline & 2 & 66 & $*$ & $*$ & 3.43 & 1.27 & $*$ & $*$ \\
\hline \multirow{2}{*}{ Job satisfaction } & 1 & 98 & 3.44 & 0.52 & 3.30 & 0.64 & 4.47 & 0.00 \\
\hline & 2 & 66 & 3.39 & 0.56 & 3.44 & 0.48 & 2.28 & 0.01 \\
\hline \multirow{2}{*}{ Emotional fatigue } & 1 & 98 & 2.19 & 0.58 & 0.76 & 4.73 & 4.55 & 0.00 \\
\hline & 2 & 66 & 2.43 & 0.62 & 0.62 & 4.82 & 4.77 & 0.00 \\
\hline \multirow{2}{*}{ Transmissive perceptions } & 1 & 98 & 3.41 & 0.54 & 3.42 & 0.59 & 3.32 & 0.00 \\
\hline & 2 & 66 & 3.36 & 0.49 & 3.37 & 0.61 & 0.86 & 0.27 \\
\hline \multirow{2}{*}{ job satisfaction } & 1 & 98 & 3.58 & 0.55 & 3.63 & 0.54 & 4.47 & 0.00 \\
\hline & 2 & 66 & 3.50 & 0.52 & 3.77 & 0.38 & 2.28 & 0.00 \\
\hline \multirow{2}{*}{ development perceptions } & 1 & 98 & 2.89 & 0.39 & 2.94 & 0.39 & 2.90 & 0.01 \\
\hline & 2 & 66 & 2.88 & 0.40 & 2.90 & 0.40 & 0.83 & 0.38 \\
\hline \multirow{2}{*}{ Efficiency teaching } & 1 & 98 & 3.00 & 0.39 & 3.02 & 0.36 & 2.63 & 0.30 \\
\hline & 2 & 66 & 3.02 & 0.34 & 3.12 & 0.38 & 1.97 & 0.50 \\
\hline
\end{tabular}


have a reliability $\alpha=0.80$. The results showed that the professional development views of cooperating teachers are negatively correlated with transmission-oriented mentoring as evaluated by trainees $(\mathrm{r}=.40, \mathrm{p}<.05)$ and positively correlated with professional development oriented mentoring. While the latter association was not statistically significant due to the small sample size ( $\mathrm{r}$ $=.32, \mathrm{p}>.05$ ). This finding indicates that the assessments of future teachers coincide with the perceptions of their cooperating teachers about learning to teach, suggesting that trainee assessments are useful indicators of the quality of mentoring.

Descriptive statistics of mentoring practices

We indicate in table 2 , the results of mentoring focused on transmission were significantly lower than the theoretical average of 3.5 in the 1 st group $(\mathrm{t}=$ $2.69, \mathrm{p}<0.05$ ), while the values of mentoring focused on sustainable professional development significantly exceeded the theoretical average in both groups (group $1: \mathrm{t}=15.23, \mathrm{p}<.05$ group $2: \mathrm{t}=12.62, \mathrm{p}<.05$ ). Table 2 presents the means and standard deviations of the variables evident for each group at both levels of measurement. The results show statistically significant changes in different variables and groups. The effectiveness of future teachers decreased significantly $(\mathrm{t}=2.63, \mathrm{p}=0.03)$ in the first group and increased, but not significantly, in the second group. There has been a significant change in the transmissive and professional development perceptions of future first group teachers. Transmissive perceptions about teaching increased during the first half of the internship $(\mathrm{t}=3.32, \mathrm{p}<0.05)$, while professional development perceptions decreased $(t=2.90, p<0.05)$. We note that both groups have seen significant changes in job satisfaction and emotional fatigue. The first group showed increased emotional fatigue $(\mathrm{t}=4.55, \mathrm{p}<.05)$ and decreased job satisfaction $(\mathrm{t}=4.47, \mathrm{p}<.05)$. In the second group, however, emotional fatigue decreased $(\mathrm{t}=4.77, \mathrm{p}$ $<0.05)$ and job satisfaction increased $(\mathrm{t}=2.28, \mathrm{p}<0.05)$. Briefly, the results indicate that future teachers progressed differently during their first and second semester of training internship, which may reflect differences in the teacher training provided each semester.

Determining the level of qualification of future teachers

Data revealed separate developmental models for group 1 and 2 futures teachers. The study findings showed that the unlimited model provided a better adjustment to the model data. Invariance tests showed that the restricted model produced only small changes in the overall model. The limited model, therefore, provides an appropriate representation of the complete model data. Table 3 shows the regression coefficients of the six structural equation formulas and their adjustment statistics. The predictive indicators were the measurement reference of the outcome variable as assessed at the first level of measurement and the three variables indicating the quality and frequency of mentoring.

It is shown that the regression coefficients of the model that predicts the development of teacher effectiveness indicate that the measurement reference strongly predicted teacher efficacy at the second measurement level $(\beta 1=$ $0.53, \mathrm{p}<.05$ ), which suggests that the design is highly stable between the two measurement periods. In addition, future teachers whose cooperating teachers have demonstrated a sustainable development mentoring style have shown a significant increase in teacher efficacy over the semester $(\beta 3=0.11, p<.05)$. There were no significant changes in teacher efficacy among future teachers who experienced a style of mentoring focused on transmission or who had frequent interactions with their cooperating teacher. Teachers' pleasure was strongly predicted $(\beta 1=0.56, \mathrm{p}$ $<.05)$ and a professional development mentoring style ( $\beta 3$ $=0.09, \mathrm{p}<.05)$. The professional development models of future teachers' perceptions showed a strong homogeneity between the first and second levels of measurement (transmissive perceptions: $\beta 1=0.68, \mathrm{p}<.05$; professional development perceptions $\beta 1=0.59, \mathrm{p}<.05)$. While the practice of transmissive mentoring positively predicted the development of transmissive perceptions $(\beta 2=0.08$, $\mathrm{p}<.05$ ), professional development mentoring was not significantly associated with constructivist perceptions of future teachers. Only periodic interactions with the cooperating teacher predicted negatively perceptions ( $\beta 4$ $=0.20, \mathrm{p}<0.05$ ) when all other variables of the model were controlled. This conclusion suggests that future teachers who expand professional development perceptions are less frequently in interaction with their cooperating teacher. The predictive models of future teachers are characterized by high coefficients of stability (emotional fatigue: $\beta 1=$ $0.61, \mathrm{p}<.05$; job satisfaction: $\beta 1=0.59, \mathrm{p}<.05)$. When

Table 3. Results of structural equation formulas to predict future teachers' performance $\left({ }^{*} p<.05.\right)$.

\begin{tabular}{lllll}
\hline & $\begin{array}{l}\text { Measurement } \\
\text { reference } \\
\text { Variables }\end{array}$ & $\begin{array}{l}\text { Mentoring } \\
\text { centered on } \\
\text { Transmission } \\
\end{array}$ & $\begin{array}{l}\text { Mentoring } \\
\text { centered on } \\
\text { development } \\
\boldsymbol{\beta 2}\end{array}$ & $\begin{array}{l}\text { Interaction } \\
\text { periodicity } \\
\boldsymbol{\beta} 4\end{array}$ \\
\hline Satisfaction Job & $0.59^{*}$ & 0.05 & $0.21^{*}$ & $0.4^{*}$ \\
Teacher's efficiency & $0.53^{*}$ & 0.05 & $0.11^{*}$ & 0.04 \\
Teacher's pleasure & $0.56^{*}$ & 0.05 & $0.09^{*}$ & 0.00 \\
Transmission perception & $0.68^{*}$ & $0.08^{*}$ & 0.02 & 0.04 \\
Emotional fatigue & $0.61^{*}$ & 0.09 & $0.33^{*}$ & 0.1 \\
Development perception & $0.59^{*}$ & 0.03 & 0.02 & $0.2^{*}$ \\
\hline
\end{tabular}


the reference levels were tested, future teachers who received professional development mentoring showed a statistically significant decrease in emotional fatigue $(\beta 3=$ $0.33, \mathrm{p}<.05)$ and a statistically significant increase in Job Satisfaction $(\beta 3=0.21, p<.05)$. This clearly proves that professional development -oriented mentoring promotes the success of future teachers.

\section{Discussion}

In this study, we distinguished two mentoring practices: professional development and transmission mentoring style. We have worked out a methodology to measure the two mentoring practices and evaluate their quality. After establishing the reliability and validity of our measure, we predicted the development of future teachers based on the qualitative and quantitative characteristics of the mentoring experience. We used a pre-test and posttest study design to determine whether mentoring predicts trainees' effectiveness, motivation to teach, the perception of learning, emotional fatigue, and job satisfaction once the various reference thresholds are adjusted.

Most of the future teachers in our study participants who received professional development mentoring that provided mentoring that included opportunities for selfreflection, trying out various teaching methods, and making independent decisions. This means that many cooperating teachers provide a learning atmosphere that supports individual learning and development. This orientation to professional development mentoring can be seen as an unexpected phenomenon, as the teachers who assume the role of cooperating teacher is not qualified teacher trainers, but regular teachers chosen by the head of school. In this way, cooperating teachers have tended to choose useful monitoring practices despite their limited training. Subsequently, the results of the descriptive analyses showed that the two mentoring practices are unrelated. This means that mentoring for transmission and mentoring for professional development are two distinct practices and cannot be seen as two pillars of a single model. Our results are aligned with Bandura [39] finding, who argued that the two forms of mentoring make different theoretical suppositions about how to learn and it would not be correct to exclude either of them from research focused on the training-learning process.

There is evidence that future teacher who is experimenting with professional development mentoring show higher levels of job effectiveness, motivation and satisfaction and lower levels of emotional fatigue after a semester of training compared to teachers who have not received the same mentoring. This confirms findings of Ingersoll and Strong [16] that mentoring is an important source of support for trainees. In this study, the different mentoring practices predict the development of future teachers differently. Theoretical predictions that mentoring based on collaborative research and critical thinking have been supported. According to Jerusalem and Schwarzer [40], this theoretical prediction is helpful in developing the motivation of future teachers. In contrast, while mentoring focused on transmission has increased, trainees' transmissive perceptions do not have significant effects. In this way, it is perceived that the cooperating teachers provide close supervision of their trainees and pass on their knowledge, their teaching ideas, do not encourage the start of learning effectively. The results also showed that future teachers who interact frequently with their cooperating teachers showed fewer perceptions of professional development when the quality of mentoring instruction is taken into account. It may be hypothesized that futures teachers who receive professional development mentoring may not need close guidance and frequent interactions.

In this study, we found that the impacts of mentoring are limited in importance and this finding is similar to Hudson [41] research findings. It is important to take into account that when interpreting these impacts future teachers are also open to training offered in the university. Furthermore, Cohen [42] stated in his study that the time allocated to cooperating teachers for close cooperation with the trainee is limited by the fact that their teaching mission is not generally suited to their monitoring functions. For this reason, special attention should be paid to the fact that cooperating teachers facilitate the development of trainees despite their limited means.

\section{Conclusion}

With the results of our research, we had the opportunity to study the rate of change of future teachers over an entire university year. The methodology applied for our study is the pre-test and post-test to determine the extent to which mentoring provides for the development of trainees' motivation and perceptions. The main conclusion we drew was that centered mentoring on professional development supports the development of future teachers during pre-service training. Based on our results, we find that mentoring focused on professional development and transmission can be supported by mentoring concepts that are developed and adapted to different concepts of training theory. Findings from this study indicate that cooperating teachers should be provided with training on supervision during pre-service training. We conclude that cooperating teachers training should include supervision practice themes to provide their trainees with real practice opportunities and to support them as needed. For future studies, however, we should consider research projects with multiple measures during a university year and compare the results with other studies in countries that have examined this topic and proposed practical solutions.

\section{Acknowledgments}

The authors acknowledge the participation of the trainee students in our research.

\section{Funding}

The author(s) received no financial support for the research, authorship, and/or publication of this article.

\section{Conflict of interests}

The authors declare that there is no conflict of interests. 


\section{References}

1. Hoyle Eric, Peter D. John. Professional knowledge and professional practice. Burns \& Oates; 1995.

2. Eraut Michael. Developing professional knowledge and competence. Routledge; 2002.

3. Darling-Hammond L. The Right to Learn and the Advancement of Teaching: Research, Policy, and Practice for Democratic Education. Educational Researcher. 1996;25(6):5-17. https://doi.org/10.3102/0013189X025006005

4. Fantilli RD, McDougall DE. A study of novice teachers: Challenges and supports in the first years. Teaching and Teacher Education. 2009;25(6):814- 825. https://doi.org/10.1016/j.tate.2009.02.021.

5. Haser Ç, Star JR. Change in beliefs after first-year of teaching: The case of Turkish national curriculum context. International Journal of Educational Development. 2009;29(3):293- 302. https://doi.org/10.1016/j.ijedudev.2008.08.007

6. Kram KE. Phases of the Mentor Relationship. Academy of Management Journal. 1983; 26(4):608-25. https://doi.org/10.5465/255910.

7. Mullen CA, Kealy WA. Lifelong mentoring: The creation of learning relationships. In: Mullen CA, Lick DW. (Eds), New directions in mentoring: Creating a culture of synergy. New York: Falmer Press; 1999. P.187-199.

8. Sullivan Susan, Jeffrey Glanz. Alternative Approaches to Supervision: Cases from the Field. Journal of curriculum and supervision, 2000;15(3): 212-35.

9. Levin BB, Rock TC. The Effects Of Collaborative Action Research On Preservice And Experienced Teacher Partners In Professional Development Schools. Journal of Teacher Education. 2003 Mar;54(2):135- 149. https://doi.org/10.1177/0022487102250287.

10.Melki H, Sami Bouzid M, Hawani A, Mrayeh M, Souissi N. Identification of Prevailing Roles to Which Tunisian Cooperative Teachers (CT) Attach a Big Importance in Accompanying Teacher Students (TS). Creative Education. 2016;07(09):1244-52. https://doi.org/10.4236/ce.2016.79131

11.Kirk David, Doune Macdonald, Mary O'Sullivan. Research into elementary physical education programs. 2006.

12.Keogh Jayne E, Shelly L Dole, Elizabeth Hudson. Supervisor or mentor? Questioning the quality of pre-service teacher practicum experiences. Australian Association for Research in Education [AARE] 2006 International Education Research Conference. 2006; 1: 15-20

13.Clarke J. Energy Simulation in Building Design [Internet]. 2nd ed. Routledge; 2007 [cited 2018 Dec 24]. Available from: https://www.taylorfrancis.com/books/9780080505640 https://doi.org/10.4324/9780080505640

14.Gratch, Jonathan. Modeling the interplay between emotion and decision-making. Proceedings of the 9th Conference on Computer Generated Forces and Behavioral Representation. 2000.

15.Beck C, Kosnik C. Associate Teachers in Pre-service Education: Clarifying and enhancing their role. Journal of Education for Teaching. 2000;26(3):207-24. https://doi.org/10.1080/713676888.

16.Ingersoll RM, Strong M. The Impact of Induction and Mentoring Programs for Beginning Teachers: A Critical Review of the Research. Review of Educational Research. 2011 Jun;81(2):201- 233. https://doi.org/10.3102/0034654311403323

17.Roberts J. From Know-how to Show-how? Questioning the Role of Information and Communication Technologies in Knowledge Transfer. Technology
Analysis \& Strategic Management. 2000;12(4):429- 443. https://doi.org/10.1080/713698499

18.Smith Dorothy E. Institutional ethnography: A sociology for people. Rowman Altamira; 2005.

19.Graham Charles R. Blended learning systems. The handbook of blended learning. 2006.

20.Marable MA, Raimondi SL. Teachers' perceptions of what was most (and least) supportive during their first year of teaching. Mentoring \& Tutoring: Partnership in Learning. 2007;15(1):25- 37. https://doi.org/10.1080/13611260601037355.

21.Lindgren U. Experiences of beginning teachers in a school-based mentoring program in Sweden. Educational Studies. 2005;31(3):251- 263. https://doi.org/10.1080/03055690500236290

22.LoCasale-Crouch J, Davis E, Wiens P, Pianta R. The Role of the Mentor in Supporting New Teachers: Associations with Self-Efficacy, Reflection, and Quality. Mentoring \& Tutoring: Partnership in Learning. 2012 Aug;20(3):303-323. https://doi.org/10.1080/13611267.2012.701959

23.Rots I, Aelterman A, Vlerick P, Vermeulen K. Teacher education, graduates' teaching commitment and entrance into the teaching profession. Teaching and Teacher Education. 2007;23(5):543- 556. https://doi.org/10.1016/j.tate.2007.01.012

24.Gagné M. The Oxford Handbook of Work Engagement, Motivation, and Self-Determination Theory [Internet]. Oxford University Press; 2014 [cited 2018 Dec 24]. Available from: http://www.oxfordhandbooks.com/ view/10.1093/oxfordhb/9780199794911.001.0001/

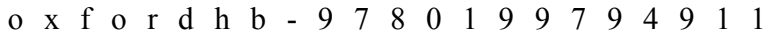
https://doi.org/10.1093/oxfordhb/9780199794911.001.0001

25.Nevins Stanulis R, Floden RE. Intensive Mentoring as a Way to Help Beginning Teachers Develop Balanced Instruction. Journal of Teacher Education. 2009;60(2):112- 122. https://doi.org/10.1177/0022487108330553

26.Ganser T. How Teachers Compare the Roles of Cooperating Teacher and Mentor. The Educational Forum. 2002;66(4):380-5. https://doi.org/10.1080/00131720208984858

27.Brooks V, Barker S, Swatton P. Quid Pro Quo? Initial Teacher Education in Secondary Schools. British Educational Research Journal. 1997;23(2):163-178. https://doi.org/10.1080/0141192970230204

28.Seibert S. The Effectiveness of Facilitated Mentoring: A Longitudinal Quasi-Experiment. Journal of Vocational Behavior. 1999;54(3):483-502. https://doi.org/10.1006/jvbe.1998.1676

29.Rhodes JE. A Model of Youth Mentoring. In: Handbook of Youth Mentoring [Internet]. 2455 Teller Road, Thousand Oaks California 91320 United States: SAGE Publications, Inc.; 2005 [cited 2018 Dec 24]. p. 30-43. Available from: http://sk.sagepub.com/reference/hdbk_youthmentor/n3.xml https://doi.org/10.4135/9781412976664.n3

30.Olds D, Kitzman H, Cole R, Robinson J. Theoretical foundations of a program of home visitation for pregnant women and parents of young children. Journal of Community Psychology. 1997;25(1):9-25. h t t p s : / / d o i . org/ 10 . 1002 / ( S I C I ) 1520 6629(199701)25:1<9::AID-JCOP2>3.0.CO;2-V

31.Sfard A. On Two Metaphors for Learning and the Dangers of Choosing Just One. Educational Researcher. 199827(2):4-13. https://doi.org/10.3102/0013189X027002004

32.Wang J, Odell SJ. Mentored Learning to Teach According to Standards-Based Reform: A Critical Review. Review 
of Educational Research. 2002 Sep;72(3):481-546. https://doi.org/10.3102/00346543072003481

33.Collins NL, Miller LC. Self-disclosure and liking: a metaanalytic review. Psychol Bull. 1994;116(3):457-75.

34.Kessels C. The importance of induction programs for the well-being of beginning teachers. Annual meeting of the American Educational Research Association. New York; 2008.

35.Jones RL, Turner P. Teaching coaches to coach holistically: can Problem-Based Learning (PBL) help? Physical Education \& Sport Pedagogy. 2006;11(2):181-202. https://doi.org/10.1080/17408980600708429

36.Schwarzer R, Schmitz GS, Daytner GT. The teacher selfefficacy scale. [Internet]. 1999 [cited 2017 Dec 01]. Available from: http://www.fu-berlin.de/gesund/skalen/t_se.htm

37.Pastor DA, Barron KE, Miller BJ, Davis SL. A latent profile analysis of college students' achievement goal orientation. Contemporary Educational Psychology. 2007;32(1):8-47. https://doi.org/10.1016/j.cedpsych.2006.10.003
38. Vermunt JK, Magidson J. Latent class cluster analysis. In: Hagenaars J, McCutcheon A (Eds.), Applied latent class analysis. Cambridge: Cambridge University Press; 2002. P. 89-106.

39.BanduraA. Self-efficacy:Towardaunifyingtheoryofbehavioral change. Psychological Review, 1977; 84(2) : 191-215. https://doi.org/10.1037/0033-295X.84.2.191

40.Jerusalem M, Schwarzer R. Self-efficacy as a resource factor in stress appraisal processes. In: Schwarzer R. (Ed.), Self-efficacy: Thought control of action. Washington, DC: Hemisphere; 1992. P. 195-213.

41.Hudson P. Specific mentoring: a theory and model for developing primary science teaching practices. European Journal of Teacher Education. 2004;27(2):139- 146. https://doi.org/10.1080/0261976042000223015

42.Cohen J. Statistical power analysis for the behavioural sciences. Hillsdale, NJ, US; 1977.

\section{Information about the authors:}

Melki H.; (Corresponding author); http://orcid.org/0000-0001-5387-4279; hmelki@yahoo.fr; Higher Institute of Sport and Physical Education; Ksar Saïd 2010, MANOUBA, Tunisia.

Bouzid M.S.; http://orcid.org/0000-0002-0876-5177; med.sami.bouzid@gmail.com; Higher Institute of Sport and Physical Education; Ksar Saïd 2010, MANOUBA Tunisia.

Fathloun M.; http://orcid.org/0000-0003-3803-2086; Scopus Author ID: 35740151200; mfadhloun@yahoo.fr; Higher Institute of Sport and Physical Education; Ksar Saïd 2010, MANOUBA Tunisia.

Cite this article as: Melki H, Bouzid MS, Fathloun M. The most appropriate mentoring practice by a cooperating teacher during practical teaching internship. Physical education of students, 2018;22(6):320-326. doi:10.15561/20755279.2018.0607

The electronic version of this article is the complete one and can be found online at: http://www.sportedu.org.ua/index.php/ PES/issue/archive

This is an Open Access article distributed under the terms of the Creative Commons Attribution License, which permits unrestricted use, distribution, and reproduction in any medium, provided the original work is properly cited (http:// creativecommons.org/licenses/by/4.0/deed.en).

Received: 14.11 .2018

Accepted: 11.12.2018; Published: 26.12.2018 